\title{
Corporate Social Responsibility in the Development of Territorial Communities of Ukraine
}

\author{
By Vira Chyzh ${ }^{1}$, Tetiana Sakhno ${ }^{2}$
}

\begin{abstract}
Main modern society trends tend to transfer a number of government functions to business structures. Accordingly, discussions about the social dialogue between government and business are being arisen in the scientific community. Therefore, there is the enhanced relevance of the problem of social partnership among government, business, and employees. This requires the development of various versions of the corporate social responsibility concept. The article deals with the problem of an integrated approach to the essence of corporate social responsibility. Enterprises and authorities of territorial communities characterized by conflicting interests are determined to be the economic agents of corporate social responsibility. To reach the consensus between them, a system of corporate social responsibility management is proposed. To determine the impact of business entities on the development of territorial communities of Ukraine in the direction of improving the economic security of the territory as part of the social responsibility of modern business, the main structural activity indicators of business entities in Cherkasy region are analyzed. The results of the analysis revealed many problems in assessing such impacts. These are the absence of unified forms of social non-financial reporting as well as a non-systemic enterprise engagement in the development of the territory. To quantify the impact of business entities, an integrated impact coefficient of social responsibility of an individual business structure on the development of the territorial community is proposed. The coefficient determines the impact of the business structure on the economic growth of the territorial community, the environmental situation in the region, the level and the quality of life.
\end{abstract}

Keywords: social responsibility, socially responsible business, territorial community, non-financial reporting

\section{Introduction}

Reforming of local self-government in the form of decentralization is a priority and a large-scale process in the administrative and economic spaces of Ukraine. The problems of maximum provision for local socio-economic development through the independent functioning of individual administrative-territorial units, the creation of an effective and transparent system of local self-government, and the strengthening of civil society institutions are becoming increasingly important. State authorities have taken the necessary legislative steps that have attracted the attention of large, medium and small businesses to the socio-economic processes of adaptation of local communities to the changes caused by the reform. The cooperation between the private sector and communities stimulates the activity of local self-government bodies, accelerating the process of solving urgent problems of territorial development.

\footnotetext{
${ }^{1}$ Doctor of Economics, Professor of the Department of Accounting, Analysis and Taxation, Faculty of Economics and Management, Cherkasy State Technological University

${ }^{2} \mathrm{PhD}$ student of the Department of Accounting, Analysis and Taxation, Faculty of Economics and Management, Cherkasy State Technological University
} 


\section{Materials and Methods}

The article aims to determine the impact of corporate social responsibility on the development of territorial communities of Ukraine through the principles of voluntary activity and the obligation to maintain a balance of economic, environmental and social trends in their work. The methodological component of the study is a system of general and special methods, which allowed to offer a comprehensive approach to assessing the interaction of business structures and local authorities. The method of dialectical approach in understanding the essence of social partnership, the method of comparison and generalization in assessing the financial condition of enterprises, the index method in the comprehensive assessment of the business structure impact on the development of a territorial community were used in the process of the research. The information base of the research is the scientific developments of Ukrainian and foreign authors on the impact of the business community on the living standards of civil society, statistical materials of the State Statistics Service of Ukraine, and official publications of financial statements.

\section{Results of the Research}

The successful development of public relations between the private sector and territorial communities largely depends on the formation of new innovative management methods, principles, tools for their interaction, expanding cooperation and the presence of socially responsible behavior that promotes economic growth and ensure the welfare of the population. In modern Ukraine, the mechanism of social responsibility is a fairly new dialogue in building the partnership between the business interests and civil society. Establishing a link between corporate social responsibility (CSR) and the development of local communities requires investigation of this concept. Consideration of CSR in the management literature was started in the 50 s of the last century. Discussions on this issue have generated not only many of its definitions but also different approaches to the concept of CSR (Friedman M., 1970, [1] Goodpaster K. E., 2011 [2]). The analysis results of CSR systematized existing definitions (Kurinko R.M, 2014, [3]) indicate the lack of unambiguous interpretation. We claim the CSR consideration at different conceptual levels to be the main reason for this. One part of researchers regards CSR at the level of business units in achieving sustainable development. Another part of researchers deals with it at the state level to regulate the role and place of business in society. To determine the impact of CSR on the development of territorial communities, a comprehensive approach is advisable to be used.

CSR as a concept of voluntary activity of a company, aimed at the implementation and observance of social and environmental aspects of its commercial work and interaction among business, state and society, provides a balance of economic, social, and environmental areas of successful development. The activities of companies must meet the goals and values of society, respect human rights, ensure the quality of goods and services, protect the environment, promote sustainable development of the territory (community), carry out charitable activities, and act in accordance with applicable law and international standards. It is these categories that define socially active and 
responsible business, both in interaction with the external environment as well as within the company.

The main goal in the implementation of social partnership measures is to change the socio-economic situation of the state through its main link - a united territorial community. The achieving of the goals, objectives and processes, local governments and the private sector face, ought to increase the level of living conditions and vital activity of the population.

The introduction of social responsibility for Ukrainian companies has become a strategy in their daily activities. Socially responsible areas in the business processes of an organization are aimed to improve its work by introducing modern world practices and standards to increase the level of business excellence.

CSR has two components: mandatory and voluntary. The mandatory component is caused by the requirements of the society and it is the subject to legislation. The voluntary component is the expectation of society. It can be realized both for the benefit of the business as well as on the basis of philanthropy.

Any activity should benefit from the interaction. Business and community collaboration is not an exception. Stakeholders acquire rights and obligations and expect certain socioeconomic effects, which should satisfy all participants in the future.

The community aims to gain socio-economic stability, to increase income and effectiveness of social programs. Social cohesion and partnership between the local municipality and the private sector form the basis for their success through bilateral cooperation on the territory of the community, taking into consideration the latest approaches, financial resources, and experience of business structures.

Business structures are interested in ensuring the sustainable development of the company through increasing profits and purchasing activity of the population. Not only the location in a particular area but also the success of the community, the living conditions of the social environment through its consumers, its own staff, partners, investors are beneficial for the business. Investments of entrepreneurs into social projects create an economic or social effect, which forms the foundation for sustainable development of their company in the future. Taking into account that most Ukrainian companies export their products to more developed countries, it is extremely important to improve and maintain the prestige and reputation of the organization, its compliance with international standards. This can increase the value of Ukrainian business structures and their competitiveness in the world markets.

It should be noted that the tool of corporate social responsibility is clear for Ukraine. However, there are no specific mechanisms that help increase the role of economic entities in solving social problems and the development of territories.

The introduction of social responsibility provides interrelationship and partnership among the business entity, the state, and the public environment. The principles of transparency, accountability and ethical norms of conduct should be the basis for building long-term relationships with different stakeholder groups.

Economic agents of corporate social responsibility are enterprises and authorities of territorial communities. Their interests and expected results are different. Thus, business, as a basis for the formation of economic relations and social processes of local communities, is interested in obtaining stable profits and growing in value by improving 
the image of the enterprise, increasing the demand for products, investment attractiveness, and attractiveness of the labour market. Territorial authorities expect sustainable economic development of the region by gaining control over the social situation in the region, increasing the region's attractiveness on the labour market, consolidating the working population in the region, stable revenue to the local budget. There is a conflict between such divergent interests, in which consensus can be reached through the use of a corporate social responsibility management system. Subsystems of the business structures motivation to social responsibility, the involvement of business in solving the problems of socio-economic development of the territory, and social investments can be the components of this system.

The subsystem of the motivation of business structures to social responsibility should create an information platform for social initiatives, remove administrative barriers, provide the budget support for investment projects, provide the tax benefits with the active participation of business structures in the regional development, lease property and land on privileged conditions, and gain a positive assessment by mass media, which forms the image of the enterprise.

Involvement of business in solving the problems of socio-economic development of the territory should be carried out in the following forms:

- concluding a service or management contract (outsourcing);

- leasing of state equipment or land plots;

- concession;

- product sharing agreement;

- co-financing of innovative projects;

- joint ventures;

- public-private partnership;

- social partnership.

Social investments have a positive effect on both the micro and macro environment of the enterprise and in the territorial aspect as well as. Their effect on the microenvironment is to increase the value of the enterprise and financial efficiency, to reduce the operating costs, to increase product sales and to expand markets, to develop the staff, to increase productivity. At the macro level of the enterprise, social investments promote the establishment of links between the business community and the local community, create a favourable business environment, strengthen the reputation and trust of stakeholders, provide tax benefits, and create a positive image. The territorial aspect of social investment is manifested in the following forms: the impact of business on employment; business participation in the development of social infrastructure of the territory; environmental responsibility of business for the use of natural resources of the territory; support for socially vulnerable groups.

The elimination of the conflict of interests among economic agents of CSR leads to an increase in the level of corporate social responsibility and improves the life quality of a local community. The socially responsible business combines economic and social aspects in its own commercial activity, aims to maximize economic benefits, and, taking into account the social, ethical, environmental components, it is interested in improving the welfare of local communities, in compliance with the rules of the relationship between social entrepreneurship and economic development at the local level. 
The use of a CSR management system ensures the interaction between local authorities and the private sector located within the community. Since taxes, fees and payments from business activities go to local budgets, the principles of social culture and socially responsible business, through joint efforts, are able to solve the problem of socioeconomic renewal of local communities. The state of the territory economy determines the level of the social environment welfare, which depends on the main economic entity of the market economy - the business entity (enterprise).

To form the ideas about the degree of economic entity influence on the development of the territorial communities of Ukraine, in the direction of improving the economic security of the territory as a component of modern corporate social responsibility, the main structural indicators of their activities in Cherkasy region in 2016-2018 are analyzed (Table 1).

Table 1. The main indicators of business entities in Cherkasy region in 2016-2018

\begin{tabular}{|l|c|c|c|}
\hline Indicator & $\mathbf{2 0 1 6}$ & $\mathbf{2 0 1 7}$ & $\mathbf{2 0 1 8}$ \\
\hline The number of business entities, units, such as: & 53325 & 52754 & 54534 \\
\cline { 2 - 4 } Enterprises / natural persons-entrepreneurs, units. & $8050 / 45275$ & $8864 / 43890$ & $9176 / 45358$ \\
\hline Large enterprises, units. & 9 & 10 & 11 \\
\hline Medium enterprises, units. & 436 & 440 & 474 \\
\hline Small enterprises, units. & 7605 & 8414 & 8691 \\
\hline $\begin{array}{l}\text { The number of employees engaged, thousand } \\
\text { people, including: }\end{array}$ & 201,8 & 203,7 & 219,2 \\
\cline { 2 - 4 } Enterprises / individual entrepreneurs, thousand people & $129,3 / 72,5$ & $129,9 / 73,8$ & $134,4 / 84,8$ \\
\hline $\begin{array}{l}\text { Number of employees, thousand people, including: } \\
\text { Enterprises / individual entrepreneurs, thousand people }\end{array}$ & $126,3 / 27,3$ & $126,6 / 29,9$ & $131,6 / 39,4$ \\
\hline $\begin{array}{l}\text { Volume of sold products (goods, services), million } \\
\text { UAH , of which: }\end{array}$ & 135796,1 & 164479,4 & 198145,3 \\
\cline { 2 - 4 } & $117835,6 /$ & $143444,0 /$ & $173288,6 /$ \\
Enterprises / individual entrepreneurs, thousand people & 17960,5 & 21035,4 & 24856,7 \\
\hline
\end{tabular}

Source: (State Statistics Service of Ukraine, 2020, [4], Werner I.E., 2019, [5, p. 41]).

According to the statistics of the State Statistics Service of Ukraine in Cherkasy region in 2018, 54,534 business entities were registered, $16.8 \%$ of them are enterprises, $83.2 \%$ individual entrepreneurs. In the dynamics of 2016-2018, there is an increase in the number of business entities by 1209 units. (by 2.3\%) [4].

In 2016, there were 9 large enterprises in the region $(0.1 \%$ of their total number in the region), 436 medium-sized enterprises (5.4\%), and 7,605 small enterprises (94.5\%). In 2018, their number increased and amounted to: large enterprises $-11(0.1 \%)$, medium $474(5.2 \%)$, small - 8,691 (94.7\%). Within 2016-2018, an increase in the number of enterprises in Cherkasy region was recorded: large - by 2 units $(22.2 \%)$, medium - by 38 units $(8.8 \%)$, small - by 1,086 units $(14.3 \%)$ [5].

In the field of entrepreneurship in 2018, the number of employed workers amounted to 219.2 thousand people (by 8.6\% more than in 2016-2018). 134.4 thousand of people $(61.3 \%)$ are involved in enterprises, 84.8 thousand people $(38.7 \%)$ are involved in individual entrepreneurs, which, in terms of 2016-2018, amounted to 5.1 thousand people $(3.9 \%)$ and 12.3 thousand people $(16.9 \%)$, respectively.

Comparing to 2016-2018, the total number of employees in Cherkasy region has a tendency to increase by 17.4 thousand people $(11.3 \%)$, out of them the number of 
employees at enterprises increased by $4.1 \%$, individual entrepreneurs - by $44.3 \%$. In 2018, 171.0 thousand people were registered, where $131.6(77.0 \%)$ were involved in enterprises, and $39.4(23.0 \%)$ - in individual entrepreneurs.

In 2018 business entities of Cherkasy region sold products (goods, services) in the amount of $198,145.3$ million UAH, which is $45.9 \%$ more than in 2016. Enterprises sold products (goods, services) in the amount of $173,288.6$ million UAH (87.5\%), which is $47.1 \%$ more than in 2016, individual entrepreneurs in the amount of $24,856.7$ million UAH (12.5\%), which is 6896.2 million UAH (38.4\%) more comparing to 2016.

The following types of activity such as industry, agriculture, fisheries and forestry, construction, retail and wholesale trade, transport, repair of motor vehicles and motorcycles, warehousing, temporary accommodation and catering, courier and postal activities, insurance and financial activities, information and telecommunications; professional, scientific and technical activities, real estate activities, activities in the field of administrative and support services, health care and social assistance; education, sports, arts, entertainment and recreation and other services are recorded in the territorial context [4].

It is worth being noted that within 2016-2018 the economic situation in Cherkasy region has been improved due to the increase in the number of economic entities, employment, sales of products (works, services). That had a positive effect on the financial results of business activities and, in its turn, improved the socio-economic situation. Financial results of pre-tax enterprises of the region in 2016-2018 are given in Table 2.

Table 2. Financial results of enterprises before taxation in Cherkasy region in 2016-2018

\begin{tabular}{|c|c|c|c|c|c|}
\hline \multirow{2}{*}{ Year } & \multirow{2}{*}{$\begin{array}{c}\text { Financial result } \\
\text { (balance), } \\
\text { thousand UAH }\end{array}$} & \multicolumn{2}{|c|}{$\begin{array}{c}\text { Enterprises that made } \\
\text { a profit, thousand UAH }\end{array}$} & \multicolumn{2}{|c|}{$\begin{array}{c}\text { Enterprises that suffered } \\
\text { a loss, thousand UAH }\end{array}$} \\
\cline { 3 - 6 } & $\begin{array}{c}\text { in \% of the } \\
\text { total number } \\
\text { of enterprises }\end{array}$ & $\begin{array}{c}\text { financial } \\
\text { result }\end{array}$ & $\begin{array}{c}\text { in \% of the } \\
\text { total number } \\
\text { of enterprises }\end{array}$ & $\begin{array}{c}\text { financial } \\
\text { result }\end{array}$ \\
\hline 2016 & 6417011,1 & 80,3 & 10426897,2 & 19,7 & 4009886,1 \\
\hline 2017 & 6955026,8 & 77,7 & 10039225,1 & 22,3 & 3084198,3 \\
\hline 2018 & 9929936,2 & 78,9 & 12077850,1 & 21,1 & 2147913,9 \\
\hline
\end{tabular}

Source: (State Statistics Service of Ukraine, 2020, [4]).

According to the statistics of the region in 2016-2018, the results of the analysis show that up to $80.3 \%$ and $78.9 \%$ of the total number of enterprises respectively made a profit, which indicates the decrease in 2018 by $1.4 \%$. However, this trend had a positive financial result and increased their profits by 1650952.9 thousand UAH in 2018, but not all companies received a positive pre-tax financial result. Enterprises that suffered a loss, as a result of their activities in 2018, amounted to $21.1 \%$, which is $1.4 \%$ ahead of the situation that developed in $2016-19.7 \%$. The financial result of unprofitable enterprises in 20162018 decreased by 1,861,972.2 thousand UAH. On average, according to the results of enterprise financial activities in the region during three years, there was an increase in enterprise profits, that is evidenced by an increase in the overall financial result (balance). In the comparison of 2016-2018, profits increased by 3,512,925.1 thousand UAH. Due to the profitable activity of the private business sector, local budgets received tax and non-tax revenues as well as the revenues from capital transactions. 
The dynamic and successful development of production and economic activities of enterprises in the region undoubtedly gives society a social effect in the form of jobs, goods, tax revenues to the budgets of all the levels. However, the performance of enterprises does not reflect the level of their social responsibility. For large enterprises, it is possible to be measured on the basis of social reporting. For small enterprises, it is measured through the typology of territorial entities due to the role of small enterprises in the socio-economic development of the region.

Social (non-financial) reporting forms the company's image by reflecting information on the implementation of its strategic development plans in the economic, social and environmental components. It is a source opened for public access and serves as an informative tool for influence groups. Users of non-financial reporting are stakeholders of the company (shareholders, investors, creditors, employees, consumers, authorities) [6]. In the process of self-analysis of the performance and the formation of a nonfinancial report, the construction of social responsibility policy helps to determine the direction of its own strategic planning. Social reporting, as a tool for managing a company, has certain advantages and risks (Table 3).

Table 3. Company's advantages and risks in the formation of non-financial statements

\begin{tabular}{|l|l|}
\hline Advantages & Risks \\
\hline Develops management processes & Readiness for constructive criticism and feedback \\
\hline Forms an image & Data reliability \\
\hline Expands the partnership circle & Resource consumption \\
\hline Increases business transparency & $\begin{array}{l}\text { Awareness of direction, presentation of information in } \\
\text { the latest approaches }\end{array}$ \\
\hline $\begin{array}{l}\text { Increases the confidence of } \\
\text { stakeholders }\end{array}$ & The level of risk awareness during its formation \\
\hline $\begin{array}{l}\text { Strengthens business (partnership) } \\
\text { relationships }\end{array}$ & Awareness of the publication consequences \\
\hline
\end{tabular}

Source: compiled by the authors

Companies reporting on social aspects are more aware of the risk level of their activities and they are able to minimize them in time and improve their activities. In Ukraine, the reporting on non-financial areas of companies is a relatively new area that is at the stage of its active development. The number of companies that publicize the social side of their activities, operate in the domestic market and have Ukrainian capital is insignificant. Using the example of two business entities, which cover different areas of activity in the Ukrainian private sector of the economy, the characteristics of the main initiatives of corporate social responsibility involved in companies are given.

The company "Group DF" (Ukraine), which includes four nitrogen chemical companies, conducts corporate social responsibility in four areas:

- regional development - improving the quality of life in cities (investments in their development) in which the Group's enterprises are located. Assistance in the development of social infrastructure (reconstruction of parks, stadiums, sports grounds, playgrounds, roads), cultural and sports life;

- sponsorship and social projects - education - the desire to increase the prestige of higher and vocational education through the cooperation with educational institutions of 
Ukraine (employment of graduates, training and retraining of employees, the formation of a highly educated personnel reserve for the chemical industry); culture - organization of holidays and creation of cultural centres; transport - investment in the renewal of the transport network of cities; medicine - the creation of medical social centers; child protection - rehabilitation of children of employees in sanatoriums; ecology investments in the direction and eco-initiatives (reduction of air emissions; reduction of water resources, reuse of industrial waste, reduction of their generation and implementation of new approaches to their utilization; implementation of innovative energy efficiency and energy saving projects; restoration of land resources through environmental management according to international standards);

- cultural diplomacy - participation in cultural projects and festivals outside the country, which contributes to the opportunity to present Ukraine in a new dimension in European countries by learning about the cultural national heritage and diversity of modern Ukrainian culture [7, 8].

"Watsons Ukraine" and its "DC Ukraine" retail network operate in the format of corporate social responsibility and have four main areas:

- workplace - honest and transparent labour relations (training, advanced training, youth employment);

- environment - a ban on the use of products that contain micro plastics;

- society - official and transparent business; charitable and social projects; assistance to medical institutions; boarding school and rehabilitation centers for children with disabilities;

- market place - honesty and transparency of relations with partners [9].

At the same time, social reports do not provide information on the actual amount and sources of spending resources to finance social activities.

Improving the reliability of assessing the contribution of the business structure in the development of the territorial community can be achieved by using indices of its impact on economic growth, improving the environmental situation and quality of life and the integrated impact of social responsibility of individual business structures on the development of the territorial community [10].

The index of the business structure impact on the economic growth of the territorial community is determined by multiplying the growth index of gross value added by the index of increase in tax payments to the local budget in the reporting period compared to the base:

$\mathbf{I}_{\mathbf{1}}=\mathbf{I}_{\mathbf{a}} \cdot \mathbf{I}_{\mathbf{b}}$

where, $\mathrm{I}_{1}$ - index of the business structure impact on the economic growth of the territorial community;

$\mathrm{I}_{\mathrm{a}}$ - growth index of gross value added;

$\mathrm{I}_{\mathrm{b}}$ - index of increase in tax payments to the local budget.

The impact index of the business structure on the environmental situation in the region is defined as the product of the reduction index of harmful emissions into water sources and the reduction index of harmful emissions into the atmosphere:

$\mathrm{I}_{2}=\mathrm{I}_{\mathrm{c}} \cdot \mathrm{I}_{\mathrm{d}}$

where, $\mathrm{I}_{2}$ - impact index of the business structure on the environmental situation in the 
region;

$\mathrm{I}_{\mathrm{c}}$ - reduction index of harmful emissions into water sources;

$\mathrm{I}_{\mathrm{d}}$ - reduction index of harmful emissions into the atmosphere.

The impact index of the business structure on the level and quality of life of the population is defined as the product of the growth index of average salary of employees of an enterprise and the increase index in the number of employees of an enterprise in the reporting period compared to the base period:

$\mathrm{I}_{3}=\mathrm{I}_{\mathrm{p}} \cdot \mathrm{I}_{\mathrm{j}}$

where, $\mathrm{I}_{3}$ - impact index of the business structure on the level and quality of life of the population;

$\mathrm{I}_{\mathrm{p}}$ - growth index of the average salary of employees of the enterprise;

$\mathrm{I}_{\mathrm{j}}$ - increase index in the number of employees of the enterprise in the reporting period compared to the base period.

The integral impact coefficient of the social responsibility of an individual businessstructure on the development of the territorial community is the geometric mean of the three above-mentioned indexes:

$\mathrm{I}_{\mathrm{k}}=\sqrt{\mathrm{I}_{1} \cdot \mathrm{I}_{2} \cdot \mathrm{I}_{3}}$

where, $\mathrm{I}_{\mathrm{k}}-$ integral impact coefficient of the social responsibility of an individual business-structure on the development of the territorial community;

$\mathrm{I}_{1}$ - impact index of the business structure on the economic growth of the territorial community;

$\mathrm{I}_{2}$ - impact index of the business structure on the environmental situation in the region;

$\mathrm{I}_{3}$ - impact index of the business structure on the level and quality of life.

The results of calculating the impact coefficient of social responsibility of an individual business structure on the development of the territorial community are given in Table 4 and 5 .

Table 4. The impact coefficient calculation of social responsibility of the public jointstock company (PJSC) "Azot" (Cherkasy), as a part of "Group DF" company, on the development of the territorial community

\begin{tabular}{|l|c|c|c|}
\hline Criterion & 2017 & 2018 & $\begin{array}{c}\text { Difference } \\
2017-2018\end{array}$ \\
\hline $\begin{array}{l}\text { 1. The impact index of the business structure on the economic growth of the territorial } \\
\text { community }\end{array}$ & 2,14 & 1,19 & $-0,95$ \\
\hline growth index of gross value added & 0,42 & 0,98 & 0,56 \\
\hline index of increase in tax payments to the local budget & 5,08 & 0,20 & $-4,88$ \\
\hline 2. The impact index of the business structure on the environmental situation & 1,24 & 7,71 & 6,47 \\
\hline reduction index of harmful emissions into water sources & 0,94 & 2,40 & 1,46 \\
\hline reduction index of harmful emissions into the atmosphere & 1,32 & 3,21 & 1,89 \\
\hline 3. The impact index of the business structure on the level and quality of life & 7,64 & 10,99 & 3,35 \\
\hline growth index of the average salary of employees of the enterprise & 9,43 & 11,22 & 1,79 \\
\hline increase index in the number of employees of the enterprise & 0,81 & 0,98 & 0,17 \\
\hline $\begin{array}{l}\text { 4. Integral impact coefficient of the social responsibility of an individual business- } \\
\text { structure on the development of the territorial community }\end{array}$ & 4,50 & 10,04 & 5,54 \\
\hline
\end{tabular}

Source: ("Azot" Public Joint Stock Company, 2019, [11]), calculations are compiled by the authors 
Based on the annual financial statements of 2017-2018, the indicators were analyzed and the social responsibility influence coefficients of the chemical enterprise PJSC "Azot" (Cherkasy) on the local territory development were determined.

The enterprise impact on the territorial community economic growth in 2017 is 2.14, in 2018 it is 1.19. The discrepancy of 0.95 between the coefficients by years indicates a decrease in the activity of the business structure on the territory. The decrease in the indicator is influenced by a decrease of 4.88 (2017-2018) in tax revenues to the local budget from the company. Tax payments in 2017 amounted to 5.08, and in 2018 - to 0.20 .

In 2017, the eco-responsibility of the company was recorded at the mark of 1.24 , and in 2018 - at the mark of 7.71, which, by reducing harmful emissions into water sources and atmosphere, positively affected the environmental situation on the territory of its location by 6.47 in 2018. The positive dynamics was due to the modernization of production and compliance with the international standards in the environmental management system.

The impact of the company on the life quality of the population in terms of 2017-2018 increased by 3.35. In 2017, it was 7.64, in 2018 - 10.99. Shifts towards the improvement of the situation occurred due to the increase in salary of employees by 1.79 within the analyzed period and an increase in the number of employees by 0.17 .

Table 5. The impact coefficient calculation of the social responsibility of the "Watsons Ukraine" company, its trade network "DC Ukraine", on the development of the territorial community

\begin{tabular}{|l|c|c|c|c|}
\hline Criterion & 2017 & 2018 & $\begin{array}{c}\text { Difference } \\
2017-2018\end{array}$ \\
\hline $\begin{array}{l}\text { 1. The impact index of the business structure on the economic growth of the territorial } \\
\text { community }\end{array}$ & 1,43 & 1,51 & 0,08 \\
\hline growth index of gross value added & 1,03 & 1,06 & 0,03 \\
\hline index of increase in tax payments to the local budget & 1,39 & 1,43 & 0,04 \\
\hline 2. The impact index of the business structure on the environmental situation & \multicolumn{2}{|c|}{ No data available } \\
\hline reduction index of harmful emissions into water sources & - & - & - \\
\hline reduction index of harmful emissions into the atmosphere & - & - & - \\
\hline 3. The impact index of the business structure on the level and quality of life & 6,58 & 7,46 & 0,88 \\
\hline growth index of the average salary of employees of the enterprise & 6,27 & 7,04 & 0,77 \\
\hline increase index in the number of employees of the enterprise & 1,05 & 1,06 & 0,01 \\
\hline $\begin{array}{l}\text { 4. Integral impact coefficient of the social responsibility of an individual business- } \\
\text { structure on the development of the territorial community }\end{array}$ & 9,40 & 11,26 & 1,86 \\
\hline
\end{tabular}

Source: (Watsons Ukraine, 2020, [12]), authors' calculations

According to the results of determining and then analyzing coefficients, the indexes of social responsibility influence of the trade network "DC Ukraine", "Watsons Ukraine" company, were obtained.

The social responsibility of the network affected the economic development of the territorial community by 0.08 in terms of the analyzed years. In 2017 , the index reached 1.43 , in $2018-1.51$. In 2017-2018, the growth of the overall ratio was affected by the increase in gross value added and tax deductions to the local budget by 0.03 and 0.04 
accordingly.

Environmental initiatives took place as a part of activities and projects. Being commercial, the network has no own production. Therefore, there is no data on harmful emissions into the atmosphere and water resources.

Impact coefficients of the population living standards on the territory within the analyzed period increased by 0.88 . In 2017 , it was 6.58 , in $2018-7.46$. There was an increase in employee salaries by 6.27 (2017) and by 7.04 (2018) and there was a difference of 0.77 within years. Number of employees in terms of 2017-2018 increased by 1.05 and 1.06 respectively, with the difference of 0.01 .

It should be noted that in the overall results of the social responsibility impact of individual business structures on the development of the territorial community and the region indicate a positive result, which confirms the increase in coefficients.

Thus, in 2017-2018 PJSC "Azot" (Cherkasy) increased the integrated ratio by 5.54. In 2017, it was 4.50, in 2018 - 10.04. The trade network "DC Ukraine", "Watsons Ukraine" company, also increased the index of social responsibility by 1.86 within the analyzed period. In 2017, it was 9.40, and in $2018-11.26$.

Integral impact coefficient of the social responsibility of an individual business-structure on the development of the territorial community reflects the change in the scale of the business structure in certain areas over the period. The greater the volume of products produced by the company in the region, the amount of taxes paid to the local budget, the level of employment and salaries at the enterprise and the less harmful emissions into the environment, the higher the value of the coefficient, which indicates an increase in the contribution of a particular business structure in the development of the local community.

\section{Conclusions}

Thus, corporate social responsibility is one of the functioning mechanisms of a business structure, the effective action of which does not only increase the stability of the economic entity, but also the regional economic system as a whole. Through bilateral cooperation, a territorial community and private business, located on its territory, are able to ensure long-term sustainable development and to increase the level of socioeconomic capacity of administrative-territorial units.

\section{References}

Friedman, M. (1970). The Social Responsibility of Business is to Increase its Profits. The New York Times Magazin. URL: http://umich.edu/ thecore/doc/Friedman.pdf

Goodpaster, K. E. (2011). Corporate Conscience. Handbook of Spirituality and Business, 342-348.

Kurinko, R.M. (2008). Corporate Social Responsibility: The Search for Interpretation. Social Dimensions of Society, 11, 276-285.

State Statistics Service of Ukraine. Main Department of Statistics in Cherkasy Oblast. (2020). Data from site URL: http://www.ck.ukrstat.gov.ua/?p=stat dial pidpr

Vernera, I.Y. (2019). Statistical collection "Regions of Ukraine". State Statistics Service of Ukraine. Part II. Kyiv. 657 p. Retrieved from URL: http://www.ukrstat.gov.ua/druk/publicat/kat u/2019/zb $\angle 12 / \mathrm{zb}$ ru2ch2019.pdf 
Vorobei, V., Zhurovska, I. (2010). Non-financial reporting: a tool for corporate social responsibility. URL:https://www.ppv.net.ua/uploads/work attachments/Non-Financial Reporting UA .pdf

Corporate social responsibility Group DF: priority areas. (2015). Retrieved from URL: http://www.azot.ck.ua/content/articles/843/

OSTCHEM. Sustainability. (2020). Retrieved from URL: http://www.ostchem.com/uk/ustoychivoe-razvitie

Watsons Ukraine. Corporate social responsibility. (2020). Retrieved from URL: https://www.watsons.ua/socialresponse

Razgulina, E.D. (2014). Assessment of the impact of the largest enterprises on the socio-economic development of the territories. Economic and social changes: facts, trends, forecast, 3 (33), 223-234. URL: https://cyberleninka.ru/article/n/otsenka-vliyaniya-krupneyshih-predprivativ-na-sotsialnoekonomicheskoe-razvitie-territoriy/viewer

Public Joint Stock Company "Azot". Annual financial statements. (2019). Data from site URL: http://www.azot.ck.ua/content/news7/inform/fin\%20zvit/index.php

Watsons Ukraine. Management reporting. (2020). Data from site URL: http:// finreports.watsons.ua/ 